\section{Florida Citrus Management Practices}

\author{
J.J. Ferguson ${ }^{1}$ and G.D. Israel ${ }^{2}$
}

AdDitional INDEX WORDS. computer use, cold protection, farmer age, farm size, irrigation, management, production system

Summary. Although a major freeze has not affected the Florida citrus industry since 1989, growers continue to rank cold protection as an important information need. A moderate freeze during 1996 further emphasized the need to document current cold protection and related management practices. A statewide survey conducted in 1996 indicated that the $\mathrm{N}$ ational Weather Service and commercial radio or television were the primary sources of weather information in 1996, but when asked where they would obtain agricultural weather forecasts after 1996, growers indicated they would rely more on commercial radio or television, private meteorologists and the extension service. G rower awareness of the effectiveness of cold protection methods decreased with temperature and with grower production experience. M icrosprinklers were the most commonly used method for both cold protection and irrigation. Fifty percent of growers surveyed used computers for grove management, primarily for financial record keeping, with younger growers more likely to use computers than older growers. The percentage of growers with small groves is decreasing while the percentage of growers with large groves is increasing.

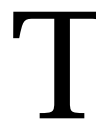
he Florida citrus industry includes $\approx 12,000$ growers (FloridaC itrusM utual, personal communication) producing $\approx 30$ grape-

\footnotetext{
Florida Experimental Station journal series R-06606. The cost of publishing this paper was defrayed in part by the payment of page charges. U nder postal regulations, this paper therefore must be hereby marked advertise ment solely to indicate this fact.

${ }^{1} \mathrm{H}$ orticultural Sciences D epartment, I nstitute of Food and Agricultural Sciences, U niversity of Florida, Gainesville, FI 32611-0690.

${ }^{2}$ Program Development and Evaluation Center, Department of Agricultural Education and Communication, Institute of Food and Agricultural Sciences, U niversity of Florida, Gainesville, FI 32611-0285.
}

fruit (Citrusparadis $M$ acf.), sweet orange [C. sinensis (L.) O sb.], mandarin (C. reticulata Blanco), and mandarin hybrid cultivars on 845,260 acres $(342,077 \mathrm{ha})$ in the 27 counties surveyed biennially by the Florida Agricultural Statistics Service (FASS, 1998). $M$ ailed surveys (Ferguson and Taylor, 1993; I srael et al., 1989; Taylor et al., 1989a, 1989b), on-site interviews of selected growers and nursery managers (Castle and Ferguson, 1982; Spyke et al., 1977; Swisher et al., 1994; Williamson and C astle, 1989), crop sampling from selected groves and nurseries (Ferguson et al., 1995; Ferguson and Schenck, 1996; Tucker et al., 1990; Zitko et al., 1987) have further identified research and extension needs and documented production practices. H owever, from 1986 to 1996 theFlorida Agricultural Statistics Service (1996) reported a loss of 479,561 acres (194,078 ha), primarily from freeze damageand again of 578,883 new acres $(234,274 \mathrm{ha})$, primarily in southern Florida, changing the profile of the Florida citrus industry. Although no major freezes have occurred since 1989, a mild freeze during J anuary $1996 \mathrm{em}$ phasized theneed to document current management practices in a restructured industry, including grovesize, location, management patterns, cold protection and related irrigation practices, and computer use, major aspects of which are presented here.

\section{Materials and methods}

A mail survey containing 21 questions on citrus management practices was conducted in 1996 using the total design method (Salant and Dillman, 1994). A disproportionate sampling procedure was used to obtain a sample population of 674 citrus growers from themailing listsof eight extension agents with responsibility for commercial production in 27 Florida counties. An introductory letter and questionnairewere sent on 17 June followed at 1-week intervals by a reminder postcard, a second letter and questionnaire for those who had not yet responded, areminder postcard and a final letter and questionnaire for those who still had not responded. Four hundred fifty oneuseable responses were returned (66\% response rate) with an expected sampling error of $\pm 4.3 \%$ at the $95 \%$ confidence level (Kalton, 1983). G rowerswho responded to the survey had groves totaling 470,000 acres $(190,209 \mathrm{ha}), 55 \%$ of the state total citrus acreage of 857,687 acres (357,369 ha) in 1996 (FASS, 1996).

$D$ ata were analyzed on a statewide basis (27 counties) and according to production system, production region, grove size, and management. Production system refers to groves that are bedded (primarily poorly drained, shallow soils in the Indian River area and southwestern Florida and nonbedded (primarily the deeply drained sandy soils of the central Florida Ridge). Production regionsincluded the central Florida Ridge, thel ndian River production area (east coast of Florida), southwestern Florida, western Florida and a multicounty category that included growerswith grovesin morethan one of theabovefour production regions. $D$ ata were also analyzed in terms of grove size: 1 to 25 acres ( 0.4 to $10.1 \mathrm{ha}$ ); 26 to 49 acres; (10.5 to $19.8 \mathrm{ha}$ ); 50 to 99 acres ( 20.2 to 40.0 ha); 100 to 499 acres (40.4 to $202.0 \mathrm{ha}$ ); 500 to 999 acres (202.4 to $404.3 \mathrm{ha}$ ); $>1,000$ acres (404.7 ha). M anagement patterns included growers who owned but did not manage their groves (owners only); those who both owned their own groves and managed the groves of others (owners or managers); caretakers who managed the groves of others (manages others); thosewho both owned their own groves and managed thegrovesof others (manages both).

In some questions, growers chose more than one response, resulting in a $>100 \%$ response. I n other casesmultiple logistic regression analysis was used because the key dependent variable was dichotomous (i.e. growers used microirrigation or did not), also resulting in a $>100 \%$ response. Bivariate associations between growers' practices and attributes of the operation (e.g., grove size, production system, region, and management) were assessed using the chi-square statistic. For analysis of computer usage among growers, multiple logistic regression wasused to assessthe net effect of the independent variables (production system, management type, operation size, operator tenure, and production region).

\section{Results and discussion}

Grove size, Location, AND MANAGeMENT. G rowers were first asked to indicate the size of their groves, county and regional location, production system, and management system. Although different grove size ranges were reported 
in a survey published in 1989 and in this survey, general comparisons can be made. On a statewide basis, $29.9 \%$ of growers said their groveswere $<49$ acres (19.8 ha) (Table 1) compared with $51.0 \%$ of growers in 1989 (I srael et al., $1989)$ reporting groves $<60$ acres $(24.3$ ha). The largest grove size categories recorded in the 1989 (I srael et al.) were groves $>600$ acres or 242.8 ha (14\%) compared with $25.3 \%$ having groves $>1,000$ acres (404.7 ha) in 1996. The percentage of growerswith small groves appears to be decreasing while the percentage of growers with large groves appears to be increasing. Grove size differencesarefurther emphasized when compared within production systems: a higher percentage of nonbedded (47.4\%) than bedded (17.2\%) growers had groves $<50$ acres (20.2 ha); $4.2 \%$ of nonbedded growershad groves $>1,000$ acres (404.7 ha) compared with $40.6 \%$ of bedded growers. The shift of the Florida citrus industry from central to southern Florida was also underscored by the change in the ratio of percentage nonbedded to bedded growersin 1989 [59/41] (Israel et al., 1989); 1992 [52/ 48] (Ferguson and Taylor, 1993); 1996 [42/58]. Survey data in 1996 were also corroborated in the 1996 Commercial Citrus Inventory (FASS, 1996) for citrusacreagein central Florida counties with primarily nonbedded groves [ 350,620 acres (141,895.9 ha)] or $42 \%$ of total acreage and in southern Florida counties with primarily bedded groves [504,291 acres $(204,086.5 \mathrm{ha})]$ or $58 \%$ of total acreage.

When the regional distribution of survey respondents was considered, the largest percentage of respondents were located on the central Florida Ridge (41.2\%), followed by the Indian River area $(26.4 \%)$, southwestern Florida $(10.2 \%)$, western Florida (19.3\%), with only $2.9 \%$ in the multicounty category. When grove size within production regions was considered, growers on the central Florida Ridge (36.6\%), in western Florida (34.5\%), and the Indian River area (26.0\%) had the highest percentage of small groves $(<50$ acres or $19.8 \mathrm{ha}$ ). The highest percentage of growers with medium size groves from 100 to 499 acres (40.4 to $202.0 \mathrm{ha}$ ) werelocated on thecentral FloridaR idge (29.0\%), Indian River (26.0\%), western Florida (23.0\%) and southwestern Florida (17.4\%). The greatest concentration of groves $>1,000$ acres (404.7 ha) was in the multicounty category
(92.3\%) but this category represented only $2.9 \%$ of all growerssurveyed. Southwestern Florida (56.5\%), Indian River (31.1\%), western Florida (16.1\%), and central Florida Ridge (13.4\%) growers also reported groves in this category. The percentage of survey respondents from each county generally matched county acreage expressed as percent of statewide acreage with the exception of several southern Florida counties that accounted for arelatively low number of survey respondents but a relatively large percentage of the acreage and several central Florida counties that accounted for a relatively large number of respondents but a relatively low percentage of the acreage. When management patterns were considered, more growers owned and managed their own groves $(57.7 \%)$ than those who managed the groves of others (18.4\%) and managed both their own groves and those of others (16.1\%). Those who owned but did not managetheir grovesconstituted thelowest percentageof growers $(7.7 \%)$.

Management deCisions afFecting COLD PROTECTION. M anagement decisions affecting cold protection include access to and interpretation of weather information, selection of cold protection methods and their effectiveness, rationale for choosing specific cold protection methods, and analysis of grove microclimates. Agricultural weather forecasts had been provided by the $\mathrm{N}$ ational Weather Service(NWS), but were discontinued in April 1996. The N WS and commercial radio or television were the primary sources of weather information in 1996 (47.9\% of growers) but when asked where they would obtain agricultural weather forecastsafter 1996, growers indicated they would rely on commercial radio or television (72.3\%), private meteorologists (20.0\%) and the extension service (31.5\%). U se of the N WS, the Cooperative Extension Ser- vice and consultants for weather information during the 1995-96 production season generally increased with grove size and the use of commercial radio or television decreased with grove size. H owever, after 1996 commercial radio or television was the most commonly cited source of weather information, regardless of grovesizeand theuse of privatemeteorologists and theextension service increased with grove size.

When deciding which methods to use for cold protection, a similar percentage of growers said they adopted $U$ niversity of Florida recommendations (34.8\%) and assessed risks based on grovehistory (37.3\%). A lower percentageindicated they adopted consultants/ suppliers' recommendations (29.7\%) and assessed the costs and benefits of particular cold protection methods (31.9\%). Other factors mentioned included: growers developing their own methods, equipment limitations, personal experience, recommendations by other growers, and water restrictions.

Growers with groves $>1,000$ acres (404.7 ha) were more likely to adopt extension recommendations for cold protection than growers with smaller groves $(50.0 \%$ and $30.0 \%$, respectively). Similarly, more growers with larger operations made cold protection decisions after assessing risk based on the grove's history than did those having smaller operations [e.g., $46.1 \%$ of those with over 1,000 acres ( $404.7 \mathrm{ha}$ ) and $28.4 \%$ with $\measuredangle 50$ acres (20.2 ha), respectively]. Interestingly, only $21.0 \%$ of growers with 10 years or less in the industry made cold protection decisions after assessing risk based on the grove's history than did those having longer tenure $(42.0 \%)$.

When growers were asked about theeffectiveness of their cold protection practices at minimum temperatures of 28,20 , and $15^{\circ} \mathrm{F}\left(-2,-7\right.$, and $\left.-9{ }^{\circ} \mathrm{C}\right)$ for

Table 1. Size and location of Florida citrus groves ( 1 acre $=0.4047 \mathrm{ha}$ ). ${ }^{z}$

\begin{tabular}{|c|c|c|c|c|c|c|}
\hline \multirow{3}{*}{$\begin{array}{l}\text { Grove } \\
\text { size } \\
\text { (acres) }\end{array}$} & & \multicolumn{5}{|c|}{ Production region } \\
\hline & & $\begin{array}{c}\text { Central } \\
\text { Florida } \\
\text { Ridge }\end{array}$ & $\begin{array}{l}\text { Indian } \\
\text { River }\end{array}$ & $\begin{array}{l}\text { S.W } \\
\text { Florida }\end{array}$ & $\begin{array}{l}\text { W. } \\
\text { Florida }\end{array}$ & Multicounty \\
\hline & Statewide & \multicolumn{4}{|c|}{$\begin{array}{c}\text { Respondents } \\
(\%)\end{array}$} & \\
\hline$<49$ & 29.9 & 36.6 & 26.0 & 13.0 & 34.5 & 0.0 \\
\hline $50-99$ & 12.9 & 13.4 & 9.2 & 8.7 & 20.7 & 0.0 \\
\hline $100-499$ & 25.3 & 29.0 & 26.0 & 17.4 & 23.0 & 7.7 \\
\hline $500-999$ & 6.7 & 7.5 & 7.7 & 4.4 & 5.8 & 0.0 \\
\hline$>1000$ & 25.3 & 13.4 & 31.1 & 56.5 & 16.1 & 92.3 \\
\hline
\end{tabular}

zM ean $\pm 4.3 \%$ at $P=0.05$. 
T able 2. I rrigation methods used by F lorida citrus growers.

\begin{tabular}{lcc}
\hline & $\mathbf{1 9 8 9 ^ { \mathbf { z } }}$ & $\mathbf{1 9 9 6}^{\mathbf{y}}$ \\
\cline { 2 - 4 } M ethod & \multicolumn{3}{c}{$\begin{array}{c}\text { Respondents } \\
\text { (\%) }\end{array}$} \\
\hline M icrosprinklers & 73.0 & 88.2 \\
D rip & 20.0 & 16.4 \\
Flood or seepage & 16.0 & 13.1 \\
Permanent overhead & 23.0 & 12.4 \\
Self-propelled water guns & 10.0 & 4.0 \\
N o irrigation & 8.0 & 18.8 \\
\end{tabular}

$\overline{z T}$ aylor et al., 1989. M ean $\pm 5.3 \%$ at $P \leq 0.05$. Respondents chose more than one method, resulting in a $>100 \%$ response.

y $\mathrm{M}$ ean $\pm 4.3 \%$ at $\mathrm{P} \leq 0.05$. Compilation of data from questions requiring a yes or no answer for each irrigation method, resulting in a $>100 \%$ response.

at least $4 \mathrm{~h}$, their confidence about the effectiveness of their cold protection practices decreased as temperatures decreased. Seventy-three percent of growersthought their practiceswereeffective at $28^{\circ} \mathrm{F}\left(-2^{\circ} \mathrm{C}\right)$, with $22.3 \%$ considering their practices somewhat effective. At $20^{\circ} \mathrm{F}\left(-7^{\circ} \mathrm{C}\right)$ only $11.9 \%$ thought their practices were very effective, with $54.8 \%$ indicating these practices were somewhat effective and $14.1 \%$ considering their practices not effective. M ore importantly, the percentage of growers who were unaware of the effectiveness of their cold protection methods increased from $4.1 \%$ at $28{ }^{\circ} \mathrm{F}\left(-2{ }^{\circ} \mathrm{C}\right)$ to $19.3 \%$ at $20^{\circ} \mathrm{F}\left(-7^{\circ} \mathrm{C}\right)$ to $51 \%$ at $15^{\circ} \mathrm{F}$ $\left(-9{ }^{\circ} \mathrm{C}\right)$. Regardless of temperature, growers with the shortest tenure in the industry were also more likely to be unaware of the effectiveness of their cold protection practices, possibly because they may not have been working as production managers in the 1989 freeze.

Cold protection practices. Cold protection methodsincluded irrigation with ground and in-treemicrosprinklers, flood or seepage, tree wraps alone, tree wrapsor treecoverswith microsprinklers, groveheaters, portableor self-propelled water guns, wind machines, and permanent overhead irrigation. A much higher percentage of growers used ground microsprinklers for cold protection (76.3\%) than flood or seepage (21.5\%), in-tree microsprinklers (17.7\%), tree wraps $(12.6 \%)$ or tree wraps or covers with microsprinklers (6.4\%) Furthermore, the use of microsprinklers for cold protection increased from $86 \%$ of respondents in 1989 (I srael et al.) to 94\% (ground microsprinklers [76.3\%] + in-treemicrosprinklers[17.7\%]) in 1996. Less than $3 \%$ of respondents indicated they used heaters, portable or self-propelled guns, wind machines, permanent overhead sprinklers or tree covers. The percentage of growers using no cold protection decreased from 30\% in 1989 (I srael et al.) to $9 \%$ in the current survey. Information about cold protection methods for young citrus trees was obtained in surveys published in 1989 (T aylor etal., 1989) and 1993 (Ferguson and Taylor, 1993) and can generally be inferred from the 1996 survey that included all citrus groves. I rrigation for cold protection of young citrus trees was used by only $8.0 \%$ of growers, according to the 1989 survey, but increased to $64.0 \%$ in 1992 and $94.0 \%$ in 1996. U se of both irrigation and another cold protection method (tree wraps, etc.) decreased from $54.0 \%$ in 1989 to $40.0 \%$ in 1992 to only $6.4 \%$ in 1996. When treewrapsareleft on young trees over an extended period of time, red, imported fireants (Solenopsisinvicta Buren) and foot rot, associated with Phytophthora ni cotianaeBredadeH aan, often cause trunk damage. Increased awareness of such problems may partially explain reduced use of tree wraps with irrigation. Tree wraps alone, frequently used to prevent rootstock sprouting and herbicide damage, were used by $40.0 \%$ of respondents in 1992 but only $12.6 \%$ in 1996 . In all three surveys from 6 to $9 \%$ of respondents did not use cold protection methods for young citrus trees.

IRRIGATION WATER SOURCES AND PRACTICES. Since irrigation systems are used for both irrigation and cold protection, growers were also asked about their irrigation practices and water sources. Growers indicated they used a number of different irrigation methods, providing a $>100 \%$ response. Statewide, $88.2 \%$ of growers said they used microsprinkler systems (an increase of $15.2 \%$ from 1989), followed by with $16.4 \%$ using drip, $13.1 \%$ using flood/ seepage, $12.4 \%$ using permanent overhead and 4.0\% using portable or self-propelled guns (Table 2). Surprisingly, $18.8 \%$ of respondents said they used no irrigation. Interestingly, permanent overhead system usage increased with tenure in the industry (ranging from $7.0 \%$ of growers with up to 10 years in the industry to $23.0 \%$ of those with over 50 years) suggesting these are legacy systems in older groves.

I rrigation methods and water sources were also assessed in terms of grove size. Growers frequently used more than one irrigation method, resulting in a $>100 \%$ response in some cases. M icrosprinkler irrigation was the most common method (ranging from $76.3 \%$ for growers with 25 acres (10.1 ha) to $97.4 \%$ of growershaving 1,000 or more acres (404.7 ha). D rip irrigation wasmost common on largegroves, with $23.3 \%$ of respondents with groves from 500 to 999 acres (202.4 to $404.3 \mathrm{ha}$ ) and $30.7 \%$ with groves $>1,000$ acres (404.7 ha) indicating they used drip irrigation, while $<8.0 \%$ of growers with under 100 acres (40.4 ha) used drip irrigation. Flood/ seepage was used by $28.9 \%$ of growers with groves $>1,000$ acres (404.7 ha), more than twice the percentage of growers with groves of all other sizes.

On astatewide basis, 77\% of growers obtained their water from deep wells [>100 ft $(30.5 \mathrm{~m})]$ with $37 \%$ using surface water and $13 \%$ using shallow wells $[<100 \mathrm{ft}(30.5 \mathrm{~m})]$. O ther sources cited were reclaimed water and spider web wells, a manifold of linked, shallow wells. U se of surface water increased linearly with grove size, from $19 \%$ of thosewith groves $<50$ acres ( 20.2 ha) to $66 \%$ of growers with groves $>1,000$ acres(404.7 ha). N ot surprisingly, growerswith bedded grovesweremorelikely to use surface water $(44.8 \%)$ and shallow wells (16.1\%) for irrigation than growers with nonbedded citrus operations ( $25.8 \%$ and $9.5 \%$, respectively).

Computer use. On a statewide basis, $49 \%$ of growers use computers for grove management. A higher percentage of growers with 1 to 10 (51\%) and 11 to $30(54 \%)$ years production experience use computers than those with 31 to $50(40 \%)$ and morethan $50(38 \%)$ years experience. $M$ oregrowerson bedded groves $(63 \%)$, primarily in southern Florida where much of the new acreage has been planted in thepast 10 years, use computers than those on nonbedded groves $(32 \%)$ in theolder citrusproduc- 
ing areas of central Florida. Computer use for grove management generally increased with grove size, with $89 \%$ of growers with the largest groves $(>1000$ acres or $404.7 \mathrm{ha}$ ) using computers but only $19 \%$ of those with groves $<49$ acres (19.8 ha), $31 \%$ of those with groves from 50 to 99 acres (20.2 to $40.0 \mathrm{ha}$ ) and 52 to $59 \%$ of those with groves between 100 and 999 acres (40.4 to $202.0 \mathrm{ha}$ ).

Software applications USED fOR GROVE MANAGEMENT. Of those respondents who used computers, $89.8 \%$ used them for financial record keeping, $41.7 \%$ for accessing weather information, $35.0 \%$ for citrus production programs, $21.0 \%$ for e-mail, $17.0 \%$ for production automation and $10.0 \%$ for word processing. The highest percentage of growers on both bedded groves (91.1\%) and nonbedded groves $(86.2 \%)$, in all production regions ( $89.4 \%$ to $97.1 \%$ ), groves of all size (82.1\%to $100 \%$ ) and all management patterns (79.6\%to 100\%) al so used computersfor financial record keeping. G rowerswith thelargest groves were morelikely to usemorespecialized computer applications, such as citrus production programs, production automation and accessing weather information. No such differences occurred with more generic applications like email and word processing.

Of the grower attributes examined, only the size of the citrus operation were significant predictors of using a computer for grove management. As the size of the operation increased, so too did the likelihood of using a computer. This is consistent with an earlier study of Florida farmers (Audirac and Beaulieu, 1991). Growers with bedded groves also were more likely to use a computer than were those with nonbedded groves. The bedded/ nonbedded difference probably is not intrinsic to the production system but, instead, reflects a combination of other grower attributes. Examination of the interrelationships among these grower attributes suggests that growers having bedded operations tend to have somewhat larger operations, manage for others or for both themselves and others, and have less experience in the citrus business. The latter also implies that younger growers are somewhat more likely to use a computer than older growers.

O neconsistent finding isthat adoption of production practices and technologies by growers increase with the size of the citrus operation, raising several questions. Are growers with larger operations better educated and more progressive than growers with smaller groves? Are researchers and extension professionalsassuming theneedsof small scalegrowers are the same as those with larger operations when, in fact, this might not be so? Is it easier to deliver educational programs to large-scale growers and, hence, create greater contact and impact with thesegrowersthan smaller-scale ones? If the answer to any of these questions is yes, then efforts to strengthen theapplicability for and outreach to small-scale growers will be needed. Otherwise we run the risk of blaming the victim when these growers fail to adopt recommended practices and technologies.

\section{Literature cited}

Audirac, I. and L.J. Beaulieu. 1991. Beneficiaries of information technologies: Thecase of agricultureand local government. S. Rural D ev. C tr., M iss. StateU niv. (Starkville) Bul. SRDC 149.

Castle, W.S. and J.J. Ferguson. 1982. Current status of greenhouse and container production of citrusnursery trees. Proc. Fla. State H ort. Soc. 95:42-46.

Ferguson, J.J. and N.C. Schenck. 1996. Arbuscular mycorrhizal fungi associated with citrus in Florida. Soil Crop Sci. Soc. Florida Proc. 55:24-27.

Ferguson, J.J., L.W. D uncan, and D.E. Norden. 1995. O ccurrence of the citrus nematode in old citrus growing regions of Florida. Soil Crop Sci. Soc. Fla. Proc. 55:58.

Ferguson, J.J. and C.L. T aylor. 1993. The 1992 citrusmanagement survey. Fla. Coop. Ext. Serv. (Gainesville) Bul. 288.

FloridaAgricultural StatisticsService. 1996. Commercial citrusinventory. Fla. Agr. Stat. Serv., O rlando.

FloridaAgricultural StatisticsService. 1998. Commercial citrusinventory. Fla. Agr. Stat. Serv., O rlando.

I srael, G.D., R.P. M uraro, G.F. Fairchild, C.L. Taylor, and W.R. Summerhill. 1989. Citrus business management. Fla. Coop. Ext. Serv. (Gainesville) Bul. PE-5.

Kalton, G. 1983. Introduction to survey sampling. Sage U niv. Paper Ser. Q uantitative applications in the social sciences, 07035. Sage Publ., Beverly H ills.

Salant, P. and D .A. D illman. 1994. H ow to conduct your own survey. Wiley, N ew York.

Spyke, P.D., L.K. Jackson, and J. Soule. 1977. Weed control in the Indian River area. Proc. Fla. State H ort. Soc. 90:14-17.

Swisher, M.E., P. Monaghan, and J.J. Ferguson. 1994. A profile of Florida's commercial organic citrus growers. Fla. Coop. Ext. Serv. (Gainesville) Cir. EES-108

T aylor, C.L., J .J . Ferguson, G.D . I srael, and W.R. Summerhill. 1989a. Citrusyoung tree care. U niv. Fla. Coop. Ext. Ser. Bul. PE-7.

Taylor, C.L., L.R. Parsons, W.R.. Summerhill, and G.D. I srael. 1989b. Citrus water management and cold protection. U niv. Fla. Coop. Ext. Ser. Bul. PE-8.

Tucker, D.P.H ., R.M.D avis, T.A. Wheaton, and S.H. Futch. 1990. A nutritional survey of south central, southwest and east coast flatwoods citrus groves. Proc. Fla. State H ort. Soc. 103:324-327.

Williamson, J.G. and W.S. Castle. 1989. A survey of Florida citrus nurseries. Proc. Fla. State H ort. Soc. 102:78-82.

Zitko, S.E., L.W. T immer, and W.S. Castle. 1987. Survey of Florida citrus nurseries for phytophthora spp. Proc. Fla. State H ort. Soc. 100:82-85. 